\title{
Impact of Covid-19 Pandemic on Liquidity and Profitability of Firms in Nigeria
}

\author{
Omaliko Emeka L. Amnim, Aipma, Okeke Prince C., Obiora Fabian C. \\ To Link this Article: http://dx.doi.org/10.6007/IJARBSS/v11-i3/9229 \\ DOI:10.6007/IJARBSS/v11-i3/9229
}

Received: 15 January 2021, Revised: 18 February 2021, Accepted: 04 March 2021

Published Online: 25 March 2021

In-Text Citation: (Amnim et al., 2021)

To Cite this Article: Amnim, O. E. L., Aipma, O. P. C., \& C., O. F. (2021). Impact of Covid-19 Pandemic on Liquidity and Profitability of Firms in Nigeria. International Journal of Academic Research in Business and Social Sciences, 11(3), 1331-1344.

\section{Copyright: (c) 2021 The Author(s)}

Published by Human Resource Management Academic Research Society (www.hrmars.com)

This article is published under the Creative Commons Attribution (CC BY 4.0) license. Anyone may reproduce, distribute, translate and create derivative works of this article (for both commercial and non-commercial purposes), subject to full attribution to the original publication and authors. The full terms of this license may be seen

at: http://creativecommons.org/licences/by/4.0/legalcode

Vol. 11, No. 3, 2021, Pg. 1331 - 1344

Full Terms \& Conditions of access and use can be found at http://hrmars.com/index.php/pages/detail/publication-ethics 


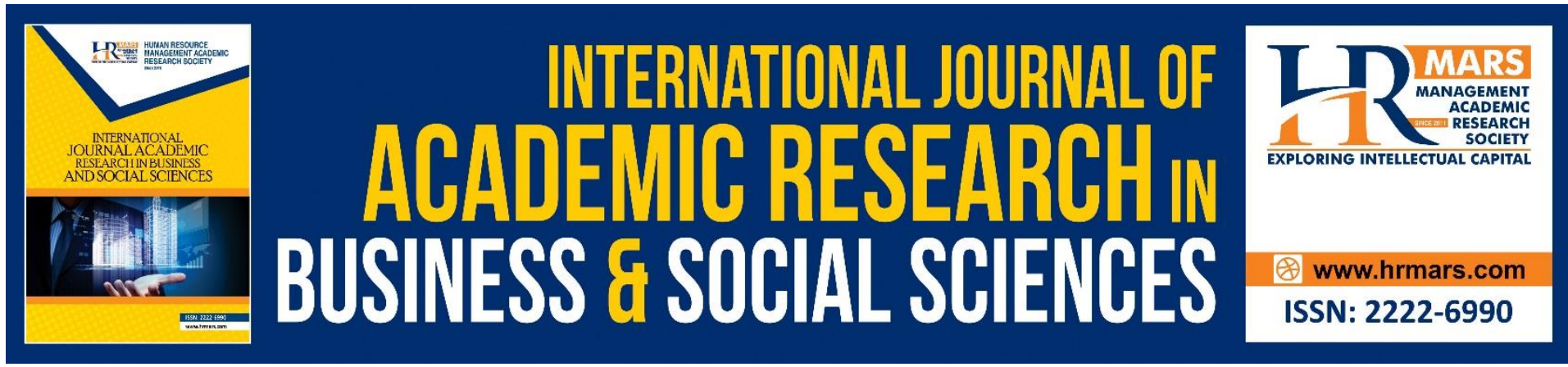

\title{
Impact of Covid-19 Pandemic on Liquidity and Profitability of Firms in Nigeria
}

\author{
Omaliko Emeka L. Ph.D, Amnim, Aipma, PDE \\ Department of Accountancy, Faculty of Management Sciences, Nnamdi Azikiwe University, \\ P.M.B. 5025 Awka, Anambra State, Nigeria. \\ Email: el.omaliko@unizik.edu.ng \\ Okeke Prince C. Ph.D \\ Department of Accountancy, Faculty of Management Sciences, Chuwkuemeka Odumegwu \\ Ojukwu University, Igbariam Campus. \\ Email: Neduokeke7@yahoo.com

\section{Obiora Fabian C. Ph.D} \\ Department of Accountancy, Faculty of Management Sciences, Chuwkuemeka Odumegwu \\ Ojukwu University, Igbariam Campus' \\ Email: oniiudochiobiora@gmail.com
}

\begin{abstract}
The study examines the impact of COVID-19 Pandemic on Liquidity and Profitability of Firms in Nigeria. The study is vital as it portrays the extent to which COVID-19 Pandemic has influenced the Liquidity and Profitability of Firms in Nigeria. In order to determine the relationship between COVID-19 Pandemic and Firms Liquidity \& Profitability, some key proxy variables were used in the study, namely Liquidity Ratio (LR), Return on Equity (ROE) while COVID-19 Pandemic was proxy by Pre COVID-19 Pandemic Period (2017-2018) and During COVID-19 Pandemic Period (2019-2020). Two hypotheses were formulated to guide the investigation and the statistical test of parameter estimates was conducted using Wilcoxon statistical test tool. The research design used is Ex Post Facto design and data for the study were obtained from the NSE Factbook. The findings of the study show that COVID-19 Pandemic has significantly affected the Liquidity and Profitability of Firms in Nigeria at 5\% level of significance. This goes further to confirm that government-imposed partial and total lockdowns during COVID-19 Pandemic increasingly hindered firms access to inputs at the local markets, difficulty in exporting and importing goods which affected both the firms liquidity and profitability negatively. Based on this, the study recommended for government to strengthen its support for local provision of raw materials since COVID-19 outbreak has greatly affected the importation of raw materials necessary for production from China in particular and other countries in general. Thus could make resource input required for production available which could enable firms maintain optimal liquidity and in turn improve firms' profitability.
\end{abstract}


Keywords: COVID-19 Pandemic, Liquidity, Profitability, Return on Equity

\section{Introduction}

COVID-19 outbreak arrived the shore of Nigeria when the country was already recovering from economic recession. The health crisis gave rise to a number of challenges such as heightened economic contraction, job losses, high inflationary pressure, increased unemployment rates, increase crime among others (Iwedi, Kocha and Onaakpono, 2020). COVID-19 pandemic actually, carries exceptional challenges. Melodramatically, there has been fall in basic demand for many goods and services, although some of the manufacturers either have shortages or are shocked. Borders are being closed around the world and Nigeria which brings change in the livelihood of the societies.

This has made entire countries come under quarantine orders making consumers around the world try to reduce human contact and manufacturers on the other hand needs to recognize that their response to the novel COVID-19 Pandemic will have a significant impact on their business. This has led companies to having challenge with liquidity and management of their cash. Management of cash is indispensable to every business that desires to meet up with its short-term financial obligations. Akinsulire (2013) asserts that the success of any business venture is predicated on how the management has planned and controlled its cash flows. According to Olowe (2018), cash management is concerned with the efficient management of cash so as to achieve an optimum level of cash in the firm's working capital. Cash represents the basic input necessary to start and keep a business running. A company needs to maintain sufficient cash to keep its business running smoothly. Cash shortage will disrupts the firm's operation and can even lead to insolvency. Excessive cash on the other hand will tie down unnecessarily long-term capital for maintaining sound cash position.

With respect to some of the foreign manufacturers who stood up to this occasion of pandemic, initiated innovative ways of dealing with the situation which enabled them to adapting to the changes they need to make to remain profitable and strong in these times. Nigeria however, has a high dependence on Chinese imports intensifies its exposure. According to National Bureau of Statistics (2019) $70 \%$ of the total import of raw material into Nigeria comes from China, on the other hand, Asia and Europe contributed 86\% of Nigeria's imports in Q4 2019. However, restrictions imposed on cross border trade has significantly slanted supply chains for manufacturers which invariably has striking effect on the Nigerian economy. Manufacturers need to be more agile, local and responsive to consumer needs, either by increasing supplies or relying more on e-commerce.

Active organizations which can definitely meet the needs of their consumers through localizing their supply chains, offering a high degree of convenience and communicating clearly with their target market, will better ride through the crisis of COVID-19 Pandemic. For most retailers and fast moving consumer goods companies (FMCGs), business continuity will depend on the quality and viability of both their suppliers and their customers. Hence the need to seek partnerships with local suppliers and distributors on innovative supply and distribution models and channels that will ensure the availability of products and services to customers and consistent customer engagement throughout this period of COVID-19 Pandemic. For example, in view of the lockdown in most cities across the world and especially Nigeria, many restaurants are offering online orders and home deliveries and in some instances refreshing their menus entirely to appeal to customers who have for the most part been home bound. In Nigeria, states like Lagos and Ogun, which are major production hubs were shut down by the government to effectively curb the spread of the virus. In lieu of this 
there is need for organizations to work in cycle with the government in order to ensure that any stimulus or actions are aligned. This can help lessen any short-term pain and potentially give way to long-term opportunities. During these uncertain times (COVID-19 Outbreak), businesses must act with integrity and empathy to navigate the current challenges and retain their customers when the crisis ends.

\section{Statement of the Problem}

Liquidity management represents an important component of working capital management (Akinyomi \& Tasie, 2011; Malik, Waseem \& Kifayat, 2011). Profitability on the other hand from the apriori expectations of Okeke (2015) is seen as a general measure of a firm's overall financial health over a given period of time. Extant literature revealed that several studies on liquidity management and profitability of firms have been conducted both in the advanced market economies and developing economies but this was before the era of COVID19 outbreak.

The lockdown of the major cities as a result of COVID-19 outbreak in Nigeria and the current foreign exchange devaluation due to drop in crude oil prices, arising from the COVID-19 Pandemic has impacted all sectors in Nigeria. This impact has been mixed as players in Food and Beverage \& Pharmaceuticals have been deemed as providers of essential products and services and as such; were allowed to continue operations during the crisis. Based on this, the need to investigate the impact of COVID-19 Pandemic on Liquidity and Profitability of Essential Goods Firms (Health Care Firms and Consumer Goods Firms) in Nigeria becomes imperative as these firms were allowed to continue operations regardless of the outbreak and total lock down in Nigeria. These firms also exploited and took the advantage of increased consumer awareness and consumption of perceived health/medicinal benefits from roots and fruits such as ginger, garlic, lime and lemon as they develop new product concepts.

Also, despite the impact of COVID-19 outbreak, we still do not know much about how COVID19 outbreak empirically impacted on the Liquidity and Profitability of Essential Goods Firms (Health Care Firms and Consumer Goods Firms) in Nigeria. And more importantly, there is no known study which had investigated the impact of COVID-19 Pandemic on firm's Liquidity and Profitability in developing countries with reference to Essential Goods Firms. Therefore, the goal of this study is to empirically test the impact of COVID-19 on Liquidity and Profitability of Essential Goods Firms' in Nigeria.

\section{Objective of the Study}

The aim of this study is to examine the impact of COVID-19 Pandemic on Liquidity and Profitability of Health Care Firms and Consumer Goods Firms in Nigeria. The specific objectives include; to

1. determine the impact of COVID-19 Pandemic on Liquidity of firms in Nigeria.

2. examine the impact of COVID-19 Pandemic on Profitability of firms in Nigeria.

\section{Research Questions}

The research questions that are set to this paper include to:

1. What is the impact of COVID-19 Pandemic on Liquidity of firms in Nigeria?

2. To what extent does COVID-19 Pandemic impacted the Profitability of firms in Nigeria? 


\section{Research Hypothesis}

In order to direct the direct flow of this study, the following hypothesis were formulated in line with objectives of the study

$\mathbf{H}_{0}$ : COVID-19 Pandemic has no significant impact on firm's Liquidity in Nigeria.

$\mathbf{H}_{0}$ : COVID-19 pandemic has no significant impact on firm's Profitability in Nigeria.

\section{Review of Related Literature COVID-19 Pandemic}

COVID-19 is traceable to Wuhan in China in the late 2019. The pandemic of COVID-19 has been affecting all spheres of human endeavour in the recent time. As the coronavirus affects public health services at global level, it also does to global economies. The pandemic of COVID-19 is worrisome because it is inevitable in leading to the global economic recession (Hope, Saidu \& Success, 2020).

World Health Organization (2020) notes that, the victim of COVID-19 will surely experience respiratory illness and older people and more importantly, people with medical or health problems such as diabetes, cancer respiratory disease among others are likely to be infected with COVID-19. It is reiterated that COVID-19 can spread easily through the nose or mucus discharge and droplets of saliva especially through sneezes and coughs (World Health Organization, 2020).

Nonetheless, the most common symptoms of the disease are fever, dry cough and tiredness. The severe symptoms are chest pain, loss of speech and difficult breathing. Globally, many lives have been taken as a result of the prevalence of coronavirus. Hence, it is important to adhere to preventive measures especially by washing hands, using sanitizers etc. as directed by the health workers (World Health Organization, 2020). Currently, there is no actual treatment and or vaccine to be taken by someone infected with the virus. Nonetheless, there are several efforts at the international level especially China, US, UK, Japan, Canada, Germany, France etc. pertaining to trail vaccines for treatment of COVID-19.

The spread of the infectious disease is still on the rise despite many efforts people and government of nations to contain it, such as containment, an individual measure of protection, the authorization of the use of Hydrochloroquine and other drugs that have not been clinically tested (Addi, Benksim, Amine \& Cherkaoui, 2020). According to NCDC (2020), the incubation period for COVID-19 is between 2-14 days. Bai, Yao, Wei, Tian, Jin, Chen and Wang, (2020) asserted that the reason for the high level of the spread of the virus on individuals across the globe as a result of the symptomatic and asymptomatic nature.

\section{Liquidity}

Omaliko and Okpala (2020) opine that liquidity indicates whether an entity could be able to meet its financial obligations in the short- term where solvency indicates the ability to meet long term financial obligation. Liquidity is also viewed traditionally as arising from financing activities where firms borrow to raise cash for operations.

Liquidity is the ability of a firm to fund increases in assets and meet obligations as they come due, without incurring unacceptable losses while effective liquidity risk management helps ensure a firm's ability to meet cash flow obligations, which are uncertain as they are affected by external events and another agents' behavior. Liquidity risk management is of paramount importance because a liquidity shortfall at a single institution can have system-wide repercussions (BCBS, 2019). In carrying out the role of financial intermediation especially as it relates to maturity transformation of short-term deposits into long-term loans, some firms 
especially banks are inherently exposed to liquidity risk both at an idiosyncratic (institutionspecific) level or system-wide. The provision of maintaining adequate liquidity always to meets customer's obligation is an essential feature of banking. Therefore, banks must ensure that adequate provision of cash and other near cash securities are made available to meet daily withdrawals obligations and new loan demands by customers in need of liquidity (BCBS, 2019). It is in this regard that banks in Nigeria are statutorily required to comply with the Cash Reserve Requirement (CRR) policy of the Central Bank of Nigeria (CBN) as well as other regulatory measures of effectively managing their liquidity positions.

Anyanwu, (2003) posits that liquidity shortage, no matter how small, can cause unimaginable disruption to a financial institution's operations and customer's relationship. Every business relies on its customers to succeed, therefore managing good customer relationships is key and should be incorporated into its strategic planning process. Liquidity crisis, if not properly managed can result to reputational risk including bad press releases against the institution and could destroy customer's relationships built over the years. In order to avoid this, it is thus imperative that the managers of businesses and financial institutions should have a welldefined business policy and established procedures for measuring, monitoring, and managing liquidity. Managing liquidity is therefore a core daily process requiring institutions to monitor and project cash flows to ensure that adequate liquidity is always maintained to meet their obligations as they arise.

For the purpose of this study, liquidity was measured using liquidity ratio as used by Wuave, Yua and Yua (2020). This is mathematically expressed as CA/CL

\section{Profitability}

Profitability is usually represented by different financial ratios such as total asset growth, loan growth rate and earnings growth rate. The performance of management is habitually a narrative expression through subjective evaluation of management systems, organizational discipline, control system, quality of staff and many more (Obim, Takon \& Mgbado, 2020). Return on Equity (ROE), Return on Assets (ROA) and Net Assets Per Share (NAPS) were used as a profitability measurement in the previous studies. Nahiba (2017) used (NAPS), Brockman (2015) used (NAPS), Oliveira, Rodrigues and Craig, (2015) used (ROE), Raheman, Salleh, Afza and Chek (2014) used (ROA and ROE), Abd. Hamid, Abdul Aziz, Dora and Said (2017) used (ROE and ROA) and Rouf (2016) used (ROE and ROA) etc.

For the purpose of this study, one accounting based measurement of Return on Equity (ROE) was used as a measurement for profitability. This was captured as Net Profit After Tax divided by Total Equity This is expressed mathematically as

$\mathrm{ROE}=\underline{\mathrm{NPAT}}$

Total Equity

\section{Theoretical Framework}

The theoretical framework gives the meaning of a word in terms of the theories on COVID-19 Pandemic such as Rational Choice Theory and Liquid Assets Theory. It assumes both knowledge and acceptance of the theory that this research work depends upon.

\section{Rational Choice Theory}

The Rational Choice Theory is also known as the Choice theory. It is an economic principle that assumes that individuals always make prudent and logical decisions that provide them with the highest and personal benefits or satisfaction. The theory is based on the assumption 
that individual tries to actively maximize their advantage in any situation and therefore consistently try to minimize their losses (Hope, Saidu and Success, 2020). According to this theory, most players in Food and Beverage \& Pharmaceuticals have been deemed as providers of essential products and services and as such; were allowed to continue operations during the crisis and these firms exploited and took the advantage of increased consumer awareness and consumption of perceived health/medicinal benefits from roots and fruits such as ginger, garlic, lime and lemon as they develop new product concepts. These firms see COVID-19 Pandemic as an opportunity for exploitation.

\section{Liquid Assets Theory}

This theory states that banks must hold large amounts of liquid assets as reserves against possible demands for payment of depositors. The theory emphasizes the need for holding short-term assets as a prudent cushion in the face of various uncertainties in business operations and the various needs of a firm. According to Nzotta (2004), the level of liquid assets depends on a firm's perceived need for liquidity, the volatility of its deposits, the state of the financial market and the level and direction of monetary policy of the government. Adequate level of liquidity is positively related with firms' profitability.

\section{Empirical Literature}

Hope, Saidu and Success (2020) examined the relationship between coronavirus pandemic outbreak and firms performance in Nigeria. The result from the linear regression revealed that Coronavirus (COVID-19) Pandemic harms both the financial and non-financial performance of private businesses in Nigeria. The study concluded that that Coronavirus (COVID-19) Pandemic harms firm performance in Nigeria.

Adegboye, Adekunle and Gayawan (2020) examine the early transmission of COVID-19 in Nigeria, and show that the COVID-19 cases in Nigeria were lower than expected. Adenomon and Maijamaa (2020) examined the impact of COVID-19 on the Nigerian Stock Exchange from the 2 nd January 2020 to 16 th April 2020. The results revealed a loss in stock returns and high volatility in stock returns during the COVID-19 period in Nigeria.

Ohia, Bakarey and Ahmad (2020) predict that the effect on COVID-19 will be severe in Africa because African countries have fragile health systems. They argue that Nigeria's current national health systems cannot respond to the growing number of infected patients who require admission into intensive care units. They suggest that Nigeria should explore available collective measures and interventions to address the COVID-19 pandemic. Jacob, Abigeal and Lydia (2020) show that the COVID-19 pandemic affected higher institutions in Nigeria through the lockdown of schools, reduction of international education, disruption of academic calendar of higher institutions, cancellation of local and international conferences, creating teaching and learning gap, loss of man power in the educational institutions, and cut in budget of higher education.

Xinhuao (2020) found that there is a significant impact between COVID-19 pandemic and the Chinese financial market such that the financial market in China have remained generally stable compared to overseas markets despite the spread of the corona virus. Iwedi, Kocha and Onakpono (2020) assessed COVID-19 global pandemic trade and impact on the Nigerian economy. The study employed descriptive methodology to evaluate Covid-19 pandemic global trade wars and its impact on the Nigerian economy. The study revealed that coronavirus crippled the Nigerian economy in terms of social, religious and economic activities while the measures taken to contain the spread of COVID-19 impacted on Nigerian 
citizens in many ways including job losses, higher prices, and damage to healthcare and seriously on education services.

Tesfaye (2020) explore the impact of COVID-19 pandemic on the Ethiopia's private banking system. Ten (10) years historical data from 2010 to 2019 was used to found that the pandemic has effect on both balance sheet and income statement of banks. Wakode (2020) studied the influence of COVID-19 on the credit exposure of a bank. The study employed the statistical tool of the multivariate analysis of variance and found that there is a significant impact between COVID-19 and bank risk metrics.

Demirgue-Kunt, Pediaza and Ruiz (2020) assessed the impact of banking sector performance during the COVID-19 crisis. The study found that the crisis and the countercyclical lending role that banks are expected to play and put banking systems under significant stress with bank stocks underperforming in their domestic market than other non-banking financial firms. Baret, Celner, O'Reilly and Shilling (2020) investigated the impact of the COVID-19 pandemic on the financial market and banks. The study found evidence of significant effects of COVID19 on the general financial markets as recently the world experienced fall in share prices, oil prices, equities and bonds' prices.

Mert and Omer (2020) investigate the impact of COVID-19 on emerging stocks markets over the period March 10-April 30, 2020. The study found that there is a negative impact of COVID19 on emerging stock markets, though this negative impact has gradually fallen and has begun to tape off since mid-April. Nuhu (2020) examined the impact of the COVID-19 on the financial market: Evidence from China and U.S.A. The study applied a regression model time series data from China COVID-19 statistics reports and trading economics from 1st of March 2020 to 25 March 2020. The study used the Shanghai Stock Exchange as a sample for China and the New York Dow Jones as a sample for the U.S.A. The study found that there is a positive significant relationship between the COVID-19 confirmed cases and all the financial markets.

Kocha, Iwedi and Barisua (2020) emphasized on COVID-19 outbreak, oil price shock and banking system liquidity. The results of the study using regression model reveal that there is a positive significant impact between COVID-19 and changes in banking system liquidity in Nigeria. On the other hand, the results of the oil price slump reveal that there is a negative significant relationship between oil price and banking system liquidity. Also the results of Johansen co-integration test reveal that the series are co-integrated that is exhibit a long run relationship. The results of the granger causality tests suggest evidence of bidirectional causality flowing from COVID-19 to banking system liquidity vice versa while there is no evidence of causality running from oil price shock to banking system liquidity vice versa. Based on this, the study concludes that COVID-19 and Oil price shocks impacted significantly on banking system liquidity in Nigeria.

\section{Methodology}

The research design used is Causal Comparative Design (Ex Post Facto Design). Causal Comparative Design was used in the study in order to compare the liquidity and profitability of before COVID-19 Pandemic Period (year 2017-2018) and that of the liquidity and profitability of during COVID-19 Pandemic Period (year 2019-2020) in order to examine the impact of COVID-19 Pandemic on liquidity and profitability of Essential Goods Firms quoted under Health Care Sector and Consumer Goods Sector of Nigerian Stock Exchange (NSE).

A purposive sampling of 5 firms each were selected from Health Care Sector and Consumer Goods Sector of Nigerian Stock Exchange (NSE) respectively as at 2021 business list covering from 2017-2018 (Pre COVID-19 Pandemic Period) and 2019-2020 (during COVID-19 
Pandemic). The choice of using 10 quoted companies on NSE could be justified based on data availability. The 10 selected firms range from (Neimeth IntI PIc, May \& Baker PIc, Pharma Deko PIc, Morison PIc, Glaxosmithline Plc, Nestle Plc, Cadbury Plc, Guinness Plc, Honeywell Flour Plc and Dangote Sugar Plc).

Data for the study were obtained from the NSE Factbook and annual reports and accounts of the firms. The collected data was analyzed using Wilcoxon statistical test tool operated with SPSS version 20. This is inline and in harmony with the apriori expectations of Tako (2016), Taiwo (2016) and Ofor, Omaliko and Okoli (2017) whose studies concentrated on examining the Pre and Post effect of treasury single account (TSA) on banking activities.

\section{Operationalization and Measurement of Variables}

The dependent variable in this study is liquidity and profitability and it were proxy using the variables as shown on the table below:

Table 1: Variable Measurements

\begin{tabular}{|c|c|c|c|}
\hline $\mathbf{S} / \mathbf{N}$ & VARIABLES & FORMULA & Apriori Expectations \\
\hline & Dependent & & \\
\hline 1 & Liquidity & $\begin{array}{l}\text { LIQ Ratio: Current Assets/ Current } \\
\text { Liabilities }\end{array}$ & Wuave, Yua and Yua (2020). \\
\hline \multirow[t]{2}{*}{2} & Profitability & ROE: Net Profit after Tax/ Equity & $\begin{array}{c}\text { Rouf (2016), Oliveira, } \\
\text { Rodrigues and Craig, (2015) }\end{array}$ \\
\hline & Independent & & \\
\hline 1 & COVID-19 Pandemic & $\begin{array}{c}\text { Measured by comparing the above } \\
\text { listed variables prior to and during } \\
\text { COVID-19 Pandemic Period }\end{array}$ & \\
\hline
\end{tabular}

\section{0: Data Presentation}

The data (i.e variables) needed for the study was shown on table 2 and were used in the data analysis of the study.

Table 2: The Data Summary of 10 Quoted Health Care Firms and Consumer Goods Firms on Nigerian Stock Exchange (NSE) before and during COVID-19 Pandemic Period.

\begin{tabular}{|c|c|c|c|c|c|c|c|}
\hline S/ & COMPANY & YEAR & $\begin{array}{l}\text { LIQUIDITY } \\
\text { (LR) }\end{array}$ & $\begin{array}{l}\text { PROFITABILITY } \\
\text { (ROE) }\end{array}$ & YEAR & $\begin{array}{l}\text { LIQUIDITY } \\
\text { (LR) }\end{array}$ & $\begin{array}{c}\text { PROFITABILITY } \\
\text { (ROE) }\end{array}$ \\
\hline & & & \multicolumn{3}{|c|}{$\begin{array}{l}\text { Before COVID-19 Pandemic } \\
\text { Period (2017-2018) }\end{array}$} & \multicolumn{2}{|c|}{$\begin{array}{c}\text { During COVID-19 } \\
\text { Pandemic Period (2019- } \\
\text { 2020) }\end{array}$} \\
\hline 1 & $\begin{array}{l}\text { Neimeth Intl } \\
\text { Plc }\end{array}$ & 2017 & 1.37 & $(0.51)$ & 2019 & 1.39 & 0.21 \\
\hline & & 2018 & 1.49 & 0.19 & 2020 & 2.34 & 0.17 \\
\hline 2 & $\begin{array}{c}\text { May \& Baker } \\
\text { Plc }\end{array}$ & 2017 & 1.48 & 0.11 & 2019 & 1.12 & 0.07 \\
\hline & & 2018 & 1.06 & 0.09 & 2020 & 1.10 & 0.06 \\
\hline 3 & $\begin{array}{c}\text { Pharma Deko } \\
\text { Plc }\end{array}$ & 2017 & 1.25 & 0.01 & 2019 & 0.73 & $(0.21)$ \\
\hline & & 2018 & 0.94 & $(0.17)$ & 2020 & 0.62 & $(0.16)$ \\
\hline 4 & Morison Ind Plc & 2017 & 0.40 & 4.81 & 2019 & 0.56 & 0.70 \\
\hline & & 2018 & 0.87 & $(0.75)$ & 2020 & 0.54 & $(0.29)$ \\
\hline
\end{tabular}




\begin{tabular}{|c|c|c|c|c|c|c|c|}
\hline 5 & Glaxosmith Plc & 2017 & 2.59 & 0.07 & 2019 & 1.71 & 0.05 \\
\hline & & 2018 & 1.95 & 0.07 & 2020 & 1.51 & 0.05 \\
\hline 6 & Nestle Nig Plc & 2017 & 0.93 & 0.75 & 2019 & 0.85 & 1.00 \\
\hline & & 2018 & 0.96 & 0.86 & 2020 & 0.77 & 0.20 \\
\hline 7 & Cadbury Nig Plc & 2017 & 1.14 & 0.03 & 2019 & 1.53 & 0.08 \\
\hline & & 2018 & 1.39 & 0.06 & 2020 & 1.37 & 0.04 \\
\hline 8 & Guiness Nig Plc & 2017 & 0.90 & 0.04 & 2019 & 1.21 & 0.06 \\
\hline & & 2018 & 1.28 & 0.08 & 2020 & 0.89 & $(0.17)$ \\
\hline 9 & Honeywell & 2017 & & & 2019 & & 0.00 \\
\hline & Flour Plc & & 0.49 & 0.08 & & 0.73 & 0.01 \\
\hline 10 & $\begin{array}{c}\text { Dangote Sugar } \\
\end{array}$ & 2018 & 0.77 & 0.08 & 2020 & 0.69 & 0.21 \\
\hline & & 1.42 & 0.43 & 2019 & & 1.29 & 0.10 \\
\hline
\end{tabular}

Source: Compiled from the NSE Factbook and Annual Reports and Accounts of the Selected Firms for the year ended 2017-2020.

\section{Test of Hypotheses}

Wilcoxon Statistical Test Tool was developed to test the linear relationship between the dependent and independent variables. It was operated using SPSS version 20 as shown in the table 4.1.1- 4.1.2 below:

Table 4.1.1: Result on impact of COVID-19 Pandemic on Liquidity of Firms in Nigeria.

\section{Hypothesis Test Summary}

\begin{tabular}{|c|c|c|c|c|}
\hline & Null Hypothesis & Test & Sig. & Decision \\
\hline 1 & $\begin{array}{l}\text { The median of differences betwe } \\
\text { LR BEFGRE CDVID-19 and LR } \\
\text { DURING COVID- } 19 \text { equals } 0 \text {. }\end{array}$ & $\begin{array}{l}\text { Related- } \\
\text { eqamples } \\
\text { Uúfilcoxon } \\
\text { Signed Rank } \\
\text { Test }\end{array}$ & .008 & $\begin{array}{l}\text { Reject the } \\
\text { null } \\
\text { hypothesis. }\end{array}$ \\
\hline
\end{tabular}

Asymptotic significances are displayed. The significance level is .05 . 
Table 4.1.2: Result on impact of COVID-19 Pandemic on Profitability of Firms in Nigeria

\section{Hypothesis Test Summary}

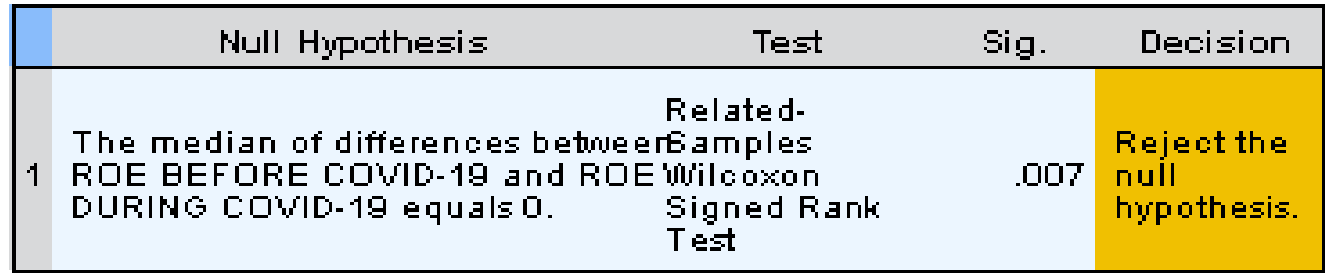

Asymptotic significances are displayed. The significance level is .05 .

\section{Discussion of Findings}

The result of the analysis of the study using Wilcoxon test tool operated with SPSS version 20 is expressed as follows:

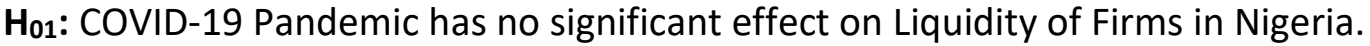

In view of the above analysis as shown on table 4.1.1, the result shows that there is a significant positive difference in the Liquidity Ratio of firms before COVID-19 Pandemic Period and the Liquidity Ratio firms during COVID-19 Pandemic Period which goes further to confirm that COVID-19 outbreak affected the liquidity of essential goods firms in Nigeria grossly. This could be justified with a P-value of 0.008 as shown on table 4.1.1; the test is considered statistically significant. As such the null hypothesis was rejected as suggested by the decision rule shown on the table.

The finding of the study is in consonance with the apriori expectations of Kocha, Iwedi and Barisua (2020) and Wakode (2020) who found that COVID-19 Pandemic has significant positive impact on firms' liquidity

H02: COVID-19 Pandemic has no significant effect on Profitability of Firms in Nigeria.

In view of the above analysis as shown on table 4.1.2, the result shows that there is a significant positive difference in the ROE of firms before COVID-19 Pandemic Period and the ROE of firms during COVID-19 Pandemic Period. This goes further to explain that COVID-19 outbreak affected the return on equity (ROE) of firms positively. COVID-19 Pandemic reduces the return on equity (ROE) of firms as suggested by the study as shown on table 4.1.2. With a p-value of 0.007 , the test is considered statistically significant. As such the null hypothesis was rejected as suggested by the decision rule shown on table 4.1.2.

This is in agreement with the findings of Hope, Saidu and Success (2020) and Demirgue-Kunt, Pediaza and Ruiz (2020) who noted significant positive association between firms performance and COVID-19 outbreak.

\section{Conclusion}

The study from the statistical analysis concludes that COVID-19 Pandemic has significant impact on liquidity and profitability of firms' in Nigeria.

\section{Recommendation}

Based on findings of the study, the following recommendations are suggested:

1. Since the study noted that COVID-19 Pandemic affected firms' liquidity in Nigeria, it was recommended that government should strengthen its support for local provision 
of raw materials since COVID-19 outbreak has greatly affected the importation of raw materials necessary for production from China in particular and other countries in general. This recommendation if met, could enable the organizations to maintain and achieve optimal level of liquidity even after the pandemic.

2. The study having observed also that COVID-19 Pandemic affected firms' profitability in Nigeria; the study recommends that government should include private businesses in its stimulus packages or palliatives programmes to keep private businesses in operation after the pandemic. This recommendation if met, could benefit firms in Nigeria to achieve a greater height (profitability).

\section{Contribution to Knowledge}

i. This study contributes important new empirical analysis of the impacts of COVID-19 Pandemic on Liquidity and Profitability of Firms in Nigeria at a point where there is an abundance of conceptual papers and opinion pieces on other aspects of the impact of COVID19 but still scarce evidence on the effect of COVID-19 Pandemic on Liquidity and Profitability of Firms, particularly in developing countries like Nigeria.

ii. The study also contributed to knowledge through the conceptual model developed and designed for the study. It is shown below as

\section{Independent Variables}

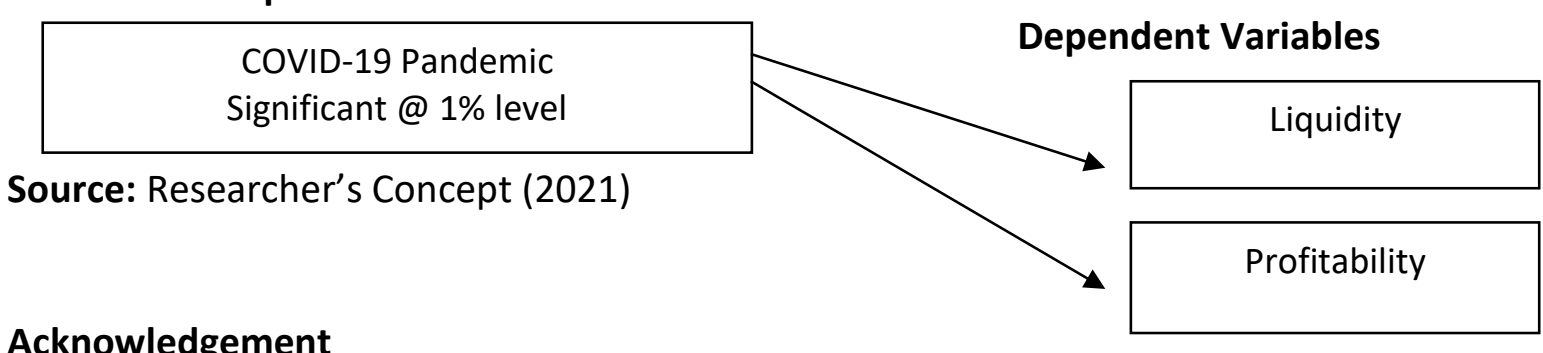

All the staff of Accountancy Department, Nnamdi Azikiwe University and Chukwuemeka Odumegwu Ojukwu University are highly acknowledged and appreciated for their positive contribution in seeing this research through. All authors whose works are used and cited on in the study are also appreciated too for their earnest contribution in this work.

\section{References}

Abd. Hamid, S., Abdul Aziz, T., Dora, K., \& Said, I. (2017). Intellectual capital disclosure and firms performance in France. Journal of Economics, Finance and Management Sciences, 4(2), 95-111.

Addi, R. A., Benksim, A., Amine, M., \& Cherkaoui, M. (2020). Asymptomatic COVID-19 infection management: The key to stopping COVID-19, Journal of Clinical and Experimental Investigations, 11(3), 1-2.

Adegboye, O. A., Adekunle, A. I., \& Gayawan, E. (2020). Early Transmission Dynamics of Novel Coronavirus (COVID-19) in Nigeria, International Journal of Environmental Research and Public Health, 17(9), 3054.

Adenomon, M. O., \& Maijamaa, B. (2020). On the Effects of COVID-19 outbreak on the Nigerian Stock Exchange performance: Evidence from GARCH Models.

Akinsulire, O. (2013). Financial management, $\left(4^{\text {th }}\right.$ ed), Nigeria: Ceemol Nigeria Limited 
Akinyomi, O., \& Tasie, C. (2011). Effect of working capital management on the profitability of Nigerian manufacturing firms, International Journal of Management and Enterprise Development, 8(1), 57-62

Anyanwu, J. C. (2003). Monetary Economics: Theory, Policy and Institutions, Benin City: Hybrid Professional Publishers Ltd,

Bai, Y., Yao, L., Wei, T., Tian, F., Jin, D, Y., Chen, L., \& Wang, M. (2020). Presumed asymptomatic carrier transmission of COVID-19. JAMA

Baret, S., Celner, A., O'Reilly, M., \& Shilling, M. (2020). Covid-19 potential implications for the banking and capital markets sector, Maintaining business and operational resilience. Deloitte Insights.

BCBC. (2019). Basel committee on banking supervision; banks for international settlement, basel III monitoring reports

Brockman, T. (2015). Social corporate disclosure and firms performance, evidence from list manufacturing firms' in Italy. Journal of Science, 4(9), 45-52.

Demirgue-Kunt, Pedraza \& Ruiz. (2020). Banking sector performance during the Covid -19 crises. The World Bank Policy Research working paper series, 9363.

Hope, O., Saidu, M., \& Success, A. (2020). Coronavirus pandemic outbreak and firms performance in Nigeria, Management and Human Resource Research Journal, 9(4), 15-25

Iwedi, M., Kocha, C. N., \& Onakpono, A. E. (2020). Covid-19 pandemic, global trade wars and impact on the Nigeria Economy. Academic Journal of Current Research, 7(5), 71-82.

Jacob, O. N., Abigeal, I., \& Lydia, A. E. (2020). Impact of COVID-19 on the Higher Institutions Development in Nigeria, Electronic Research Journal of Social Sciences and Humanities, 2, 126-135.

Kocha, C., Iwedi, M., \& Barisua, S. (2020). COVID-19 outbreak, oil price shock and banking system liquidity: the Nigeria Evidence, Greneer Journal of Economics and Accountancy, 8(1), 6-11

Malik, M., Waseem, J., \& Kifayat, U. (2011). Working capital management and profitability an analysis of firms of textile industry of Pakistan, Journal of Managerial Sciences 6(2), 155-165

Mert, T., \& Omer, S. G. (2020). The impact of COVID-19 on emerging stock markets, Finance Research Letter 36, 1-6

Nahiba, M. (2017). Non financial disclosures and performance of manufacturing firms in India, Journal of Empirical Literature, 7(9), 21-29.

NCDC. (2020) First Case of Corona Virus Disease Confirmed In Nigeria https://ncdc.gov.ng/news/227/first-case-of-corona-virus-disease-confirmed-innigeria retrieved on May 11, 2020

Nigeria Bureau of Statistics. (2019). Statistics on COVID-19 Pandemic in Nigeria

Nuhu, S. (2020). The impact of the Covid-19 on the financial markets: Evidence from China and USA, Electronic Research Journal of Social Sciences and Humanities, 2(2), 27068242)

Nzotta, S. M. (2004). Money, Banking and Finance: Theory and Practice (2 ${ }^{\text {nd }}$ ed.). Owerri: Hudson-Jude Nigeria Publishers.

Obim, E. N., Takon, S. M., \& Mgbado, M. U. (2020). The impact of liquidity on banks profitability in Nigeria, International Journal of Banking and Finance Research, 6(1), 18 
Ofor, N., Omaliko, E., \& Okoli, C. (2017). Effect of TSA on the performance of MDAs in Nigeria, Trendy Economics and Management, 29(2), 59-67

Ohia, C., Bakarey, A. S., \& Ahmad, T. (2020). COVID-19 and Nigeria: Putting the realities in context, International Journal of Infectious Diseases

Okeke, N. (2015). Financial performance synergies, empirical review. European Accounting Review, 1(3), 55-59.

Oliveira, J., Rodrigues, L. L., \& Craig, R. (2015). The level of risk management disclosure in Australia. Managerial Auditing Journal, 26(9), 817-839.

Omaliko, E., \& Okpala, N. (2020). Effect of TSA on solvency of listed deposit money banks in Nigeria, World Journal of Finance and Investment Research, 5(1), 32-47

Raheman, Salleh, Afza and Chek, I. (2014). Non-Financial Information Disclosure Influence and its influence on Firms' Profitability in Malaysia. International Journal of Academic Research in Accounting, Finance and Management Sciences, 4(4), 297-306

Rouf, A. (2016). Corporate governance disclosures and financial performance; evidence from listed firms in Japan. Journal of Finance, 2(3), 34-38

Taiwo, M. (2016). Treasury single account and cash flow of banks, Research Journal of Finance and Accounts, 6(2), 34-36

Tako, T. (2016). Implications of treasury single account on banking activities, Journal of Finance, 4(3), 23-25

Tesfaye, B. L. (2020). The impact of Covid-19 on the Ethiopian private banking system. Published PhD thesis of University of South Africa.

Wakode, S. (2020). Efficacious scrutinizing of COVID-19 impact on banking using credit risk metrics, International Journal of finance and Banking Research, 6(3), 51-56

World Health Organization. (2020). Coronavirus disease (COVID-19) pandemic, Retrieved June 16, 2020, from https://www.who.int/

Wuave, T., Yua, H., \& Yua, P. (2020). Effect of liquidity management on the financial performance of banks in Nigeria, European Journal of Business and Innovation Research, 8(4), 30-44

Xinhuao. (2020). China Financial market remains stable and Covid-19 impact, China DailyHong Kong 